\title{
Climate Change and CCS Technologies: Managerial and Political Issues
}

\author{
Eur Ing Prof Dr Paul James \\ Graduate School, Bangkok University, Klong-Toey, Rama 4 Road, Bangkok 10110, Thailand \\ E-mail: paul.j@bu.ac.th
}

Received: December 19, 2019

Accepted: January 8, 2020

Published: January 19, 2020

doi:10.5296/emsd.v9i1.16070

URL: https://doi.org/10.5296/emsd.v9i1.16070

\begin{abstract}
Emissions of carbon dioxide appears to have risen to levels that have negative effects on the climate. These levels will continue to rise, taking the world's average temperature over the Kyoto 1997 agreed $1.5^{\circ} \mathrm{C}$ temperature. To date, only $20 \mathrm{Mn}$ tonnes of $\mathrm{CO}_{2}$ has been permanently sequestered. This is a research paper that is focused on assessing issues relating to $\mathrm{CO}_{2}$ sequestration through Carbon Capture and Storage (CCS) technologies and its impacts on managerial developments.

An interpretive methodology was utilised in order to help understand the senior research management perceptions of leading research groups underpinning CCS developments and climate change implications. The scope for this research was $\mathrm{CO}_{2}$ sequestration leading research teams/groups articulated across the spectrum of major Western and Eastern countries. Consequently, the population of interest was made up of 17 leading global, climate change research group principal scientist/engineers as managers, located at multiple research sites within Europe, US and Asia, with a mandated research directive to assess/investigate climate change impacts of $\mathrm{CO}_{2}$ and other gas emissions for governments.

The research outcomes consisted of Four (4) main themes: Emissions, Socio-Political Will/Government Strategy, Technical Development and Underground Strategies, Marketing and Costs; and Fifteen (15) sub-themes underpinned by 309 conversation targets.

The paper addresses raised issues and determines outcomes and implications for managing the scope and application of CCS technologies. These indications are synthesised from major research actors in the field that show that socio-political strategies, economics and market development should be made clearer and a paradigm shift made to strengthen strategies to engage wider utilisation of CCS technologies.
\end{abstract}

Keywords: $\mathrm{CO}_{2}$ sequestration, CCS, Political strategy, Technical development, Marketing 
costs

\section{Introduction}

It has been well illustrated elsewhere that as the $\mathrm{CO}_{2}$ levels in the atmosphere rise, then so does the atmosphere's capability of heating up (Kennedy, 2009). Pre-industrial (Circa 1750) levels of $\mathrm{CO}_{2}$ show a level as 250-280ppm (IPCC, 2007). In 2015 it was 400ppm (onlyzerocarbon.org, 2018; World Meteorological Organization, 2018), which corresponds to a calculated world atmospheric temperature mean of $1.1^{\circ} \mathrm{C}$ above that in 1750 . Given this, even with small increases in the emission rates of $\mathrm{CO}_{2}$ globally by reduction of fossil fuel use (coal fired power-stations and oil fuelled cars), the temperature will not decrease from the present, and will almost certainly rise. It would appear that managing emissions alone will not be sufficient to prevent $\mathrm{CO}_{2}$ level increases (Alcalde et al., 2018). Moving the world towards sustainable development will require changes to attitudes and how countries participate in technology development relating to carbon management and capture (Maroto-Valer, 2010; Vatalis et al. 2012) as it is considered a decisive strategy in the mitigation of emissions of $\mathrm{CO}_{2}$ (Leung, Caramanna, \& Maroto-Valer, 2014). Therefore, the need to extract emissions from the atmosphere is directly linked to changing weather patterns associated with rising temperatures above those attributed to the Kyoto protocol (UNFCCC, 1997).

\section{Literature Review}

Atmosphere extraction of $\mathrm{CO}_{2}$, which was first advocated over 30 years ago (Horn \& Steinberg, 1982), has been met with little progress to date, due to economics, marketing and technology development barriers (Talbot, 2014) as the technology has been limited by the absence of coherent approaches in terms of policy decisions, infrastructure build, market definitions and price incentives (Middleton et al., 2011). However, by 2008, only 20Mn tonnes of $\mathrm{CO}_{2}$ had been sequestered successfully (Benson \& Cole, 2008). Other technologies have been contemplated, such as mineral $\mathrm{CO}_{2}$ sequestration, which was first introduced by Seifritz, (1990) but is now taken up by research groups with massive injections of research money (for example, $£ 6.1 \mathrm{Mn}$ - Cambridge, 2017). The UK government in 2012 introduced the CCS Roadmap illustrating its commitment to such developments and the need to invest (CCS Roadmap, 2012) whilst indicating a £1Bn fund for Carbon Capture and Storage (CCS) technology developments. Unfortunately, this was withdrawn in 2015, citing excessive costs (CCS Research, 2017). However, this position has since been reversed (The Clean Growth Strategy, 2017).

For the purposes of this paper, (CCS) systems include direct extraction of $\mathrm{CO}_{2}$ from the atmosphere through technologies or sequestration through saline formations (Michael et al., 2009). Other means of extraction include emissions of $\mathrm{CO}_{2}$ during carbon-burn and chemical recovery of $\mathrm{CO}_{2}$ from industrial processes (Hammond, Akwe, \& Williams, 2011). Further, adding to these techniques include their use, or permanent deposit underground either to assist in enhanced hydrocarbon recovery (Green \& Willhite, 2018), reuse (Quadrelli et al., 2011) or to permanent isolated deep geological deposits (Rackley, 2017). 
Today, CCS is primarily thought of, as large-scale capture processes, presently applied to fixed, single point sources of $\mathrm{CO}_{2}$ emissions, such as stationary emitters (e.g. Coal-fired power stations) (IPCC, 2005) and the resulting product is compressed and transported to off-site deep geological storage facilities - often at depths of $1 \mathrm{Km}$ or more (globalccsinstitute.com, 2018) during trials. However, this method appears to advocate a single solution to an issue that has another dimension whereby $\mathrm{CO}_{2}$ is directly extracted from the atmosphere (OECD, 2012). However, other uses of this process include enhanced oil recovery pumping processes (Middleton et al., 2011), where the extracted $\mathrm{CO}_{2}$ is pumped into a void or geologic reservoir left by oil extraction (Bielicki, 2009) to aid further extraction but is limited geographically from the single-point emitter. Other project orientations suggest that $\mathrm{CO}_{2}$ can be pumped to the bottom of the sea (Shearman, 2018), but the effects of this, at the local level and further afield, is presently unknown (BBC, 2019a).

There are at present 37 reported major CCS (Carbon Capture and Storage) emissions projects operating around the world (globalccsinstitute.com, 2018), leading to an approximate MTpa of power generation - 2.4; NG processing - 20.8; other gases - 6; others - 1.7). A total of $30.9 \mathrm{MTpa}$ from 4 projects. Of these, only $3.7 \mathrm{MTpa}(11.97 \%)$ is specifically treated as dedicated geological storage. Further, the Global Institute suggests that $14 \%$ of cumulative $\mathrm{CO}_{2}$ emissions must come from CCS (globalccsinstitute.com, ibid) in an attempt to meet the $2^{\circ} \mathrm{C}$ Paris agreement on Climate Change (COP21, 2015). This means simply that $14 \%$ of present $\mathrm{CO}_{2}$ emissions must be locked into CCS projects. The IEA further indicates that CCS has the potential to reduce global emissions by $20 \%$ by 2010 suggesting that as a single mechanism it will have a huge impact on reducing global warming (IEA, 2009). However, this level of reduction through CCS has not been met - even today. For example, at the moment there are 6 major projects under development with planned combined storage capacities of 9.3MTpa. However, this should be considered within the context of a world total of $\mathrm{CO}_{2}$ emissions of $35.9 \mathrm{Gt} / \mathrm{year}$ - 2014 (co2.earth, 2018). For most Western countries, considerable effort has been given to reducing pollution contaminants from the atmosphere, but very little is being done in terms of large-scale application trials of sequestration methods (Gibbins \& Chalmers, 2010).

Having raised this issue this creates the context for the research question - In what ways can CCS technology developments help manage the impact of $\mathrm{CO}_{2}$ emissions on climate change?

\section{Methodology}

Examining strategic insights into CCS technological developments relating to climate change interventions demands a qualitative inquiry to help discriminate more effectively the various issues and obstacles raised (Hill, Thompson, \& Williams, 1997). This research orientation targets research group senior managers' opinions as authoritive 'knowledge agents' (Benn et al., 2008) originating from distinctive CCS managerial project experiences. These have been determined as suitably focused on the research concerns (Cassell \& Symon, 2004) and providing material observations (Sutton \& Austin, 2015) regarding current topical practices in relation to CCS developments (Hansson \& Bryngelsson, 2009).

The research employed a semi-structured interview design process from a subjective 
knowledge perspective (Kvale, 1996). Because of the sensitivity and impact of the operating environmental issues and the lack of published research in this area, this methodology is designed for constructing appropriate contextual data outcomes (Qu \& Dumay, 2011).

Seventeen (17) leading research group/representatives located at multiple research sites within Europe, US and Asia with a mandated research directive to assess/investigate climate change impacts of $\mathrm{CO}_{2}$ and other gas emissions for governments were targeted. This closed population, were all contained within an identified research frame (Ritchie \& Lewis, 2003), which was made up of all senior-level project managers who had on-going, direct $\mathrm{CO}_{2}$ environmental sequestration project related experiences.

This work is focused on the managerial issues raised when professional groups conduct research and development of $\mathrm{CO}_{2}$ sequestration technologies. Respondents were chosen through employing the approach of a population of interest (Carman, 1990) thus ensuring empirical adequacy (Spanos, 1990) where no selected project manager was considered out of research scope. A pilot study was carried out with three (3) respondents - chosen at random from the population and excluded from the main interview process following Maxwell (2013) - leaving 14 senior managers as a focus for the main interviews. The result of which changed the language and the logic of the questions posed respondents (Kim, 2011) and created a more cognisant and rationalised question sequencing (James \& James, 2011).

All interviews were conducted in English and took approximately one hour (Ward et al., 2015), which were also recorded with permission (Duranti, 2007). Each individual was questioned using an identical set of prepared open-questions (Gray \& Wilcox, 1995), modified through the use of supplementary speculative probing questions (Punch, 2014). Each individual's verbatim transcription - was returned to each respondent for comment, correction, addition or deletion and return (Harris \& Brown, 2010). Whole-process validity (Denzin \& Lincoln, 1998) through methodological coherence (Altheide \& Johnson, 1998) was preserved by conjoining the adopted main research question to the data outcomes (Stenbacka, 2001).

In terms of the data analysis procedure, each interview was independently examined raising discernible codes/themes (Dey, 2005) relative to the thematic analysis (Glaser, 1992) using NVivo 11. No part of any interview discourse was left uncoded (Rubin \& Rubin, 2005) and the complete outcome fully represented the respondent's views through cyclic-progressive coding-sequences (James, 2015). Themes were developed out of the data interrogation where further sub-theme analysis was conducted using all available complete data sets (Harwood \& Garry, 2003). The narrative that developed was based on applying 'credibility' (Johnson, 1997) and 'dependability' (Lincoln \& Guba, 1985) in place of 'reliability' (Strauss \& Corbin, 1990). This underpins reasoning as "best explanation" (Achinstein, 1992) and assembling raised notions and ideas in new ways (Anderson, 1987) through grounded theory application (Noble \& Mitchell, 2016) and towards the most valuable outcome (James \& James, 2011). Finally, this research focus utilises authentic observations reflecting the narrative and experience level of research group leaders through robust rigour (Seale \& Silverman, 1997) and the impact of their practices (Lambsdorff, 1998) and were designed to help build an 
analysis in the 'interests of the public good' - as public funding underpins most research adopted by the research respondents.

\section{Results}

The research outcomes are illustrated below in Table 1 and consists of four (4) main themes Emissions, Socio-Political Will/Government Strategy, Technical Development and Underground Strategies, Marketing and Costs; and fifteen (15) sub-themes with 309 conversation targets. The discussion focuses on the main theme elements. The respondent's voice is revealed by the stated ad-verbatim dialogue, reflecting the direct expression of the respondent's opinion (Cassell \& Symon, 2004), where the reporting format is directly informed/derived from Gonzalez (2008) and also Daniels et al. (2007). Consequently, the explanations that are presented are considered internally coherent (Coombs, 2017) adding to the value of the consequent analysis whilst maintaining respondent confidentiality (Kaiser, 2009).

Table 1. Primary Outcomes - Research question, themes and conversation targets

\begin{tabular}{|c|c|c|c|}
\hline Research Question & & & \\
\hline $\begin{array}{l}\text { In what ways can CCS te } \\
\text { on climate change? }\end{array}$ & hnology developments help ma & nage the impact of $\mathrm{CO}_{2}$ & emissions \\
\hline Main Themes & Sub-Themes & Conversation Targets & Cited Respondent \# \\
\hline Emissions & Time-frames & 17 & $4,10,11$ \\
\hline & Politics of Emission Controls & 26 & \\
\hline & Facilitating Issues & 16 & \\
\hline & Total & 59 & \\
\hline Socio-Political/ & Political Will & 28 & $1,3,8,9$ \\
\hline Government Strategy & Dichotomy of Need & 13 & \\
\hline & Safety & 16 & \\
\hline & Legal Stance & 17 & \\
\hline & Total & 74 & \\
\hline Technical Development & Trials & 24 & $2,5,7,14$ \\
\hline and Underground & Technical Focus & 21 & \\
\hline Strategies & Government Leadership & 20 & \\
\hline & Learning from Other Systems & 14 & \\
\hline & Total & 79 & \\
\hline Marketing and Costs & Economic Model & 25 & $6,10,12,13$ \\
\hline & Enabling Technology & 31 & \\
\hline & Focus on Profit & 26 & \\
\hline & $\mathrm{CO}_{2}$ Marketing & 15 & \\
\hline & Total & 97 & \\
\hline
\end{tabular}

The results are stated here, where each sub-theme theme is placed within each respective associated main theme:

Main Theme - Emissions: 
In terms of Time-frames. one respondent (11) suggested that, ...It can't be ignored anymore. Look at the weather this summer. It can only get worse...

In terms of Politics of Emission Controls, one respondent (4) advocated that, ...The government is too short-sighted. It doesn't share the same ethos as most climate change environmentalists. Consequently, if it can't sort out the emissions, then how will it lead $\mathrm{CO}_{2}$ sequestration schemes and its storage?...

In terms of Facilitating Issues, one respondent (10) intimated that, ...Reductions in emissions don't work. We have to extract. There is no way around it. Once people understand this it will become a reality...

Main Theme - Socio-Political Will/Government Strategy:

In terms of Political Will, one respondent (3) advised that, ...Many countries don't want to do, but Western governments must lead. However, there is an enigma when first world countries sequester $\mathrm{CO}_{2}$, and third world countries continue with coal burn like China and India. This shouldn't happen...

In terms of Dichotomy of Need, one respondent (8) voiced that, ...There needs to be a binding legal requirement for all countries in the short-term to store as much $\mathrm{CO}_{2}$ as they produce. This will mean that the more efficient economies can balance their $\mathrm{CO}_{2}$ emissions to zero level. But they can also lead by sequestering an increasing amount towards reducing $\mathrm{CO}_{2}$ levels to pre-industrial states. That will be the key...

In terms of Safety, one respondent (1) enunciated that, ...Climate change is happening all around us. We need to ensure $\mathrm{CO}_{2}$ is extracted and stored safely - probably in large storage facilities underground...

In terms of Legal Stance, one respondent (9) intimated that, ...Many countries recognise the climate change issue with $\mathrm{CO}_{2}$, but are powerless to do anything about it because no country can impose any emissions reduction on any other country. As a consequence, most Western countries can go zero-carbon burn, only to have $3^{\text {rd }}$ world countries still emit $\mathrm{CO}_{2}$ a will. Legal pressures must be brought to prevent this...

Main Theme - Technical Development and Underground Strategies:

In terms of Trials, one respondent (14) advised that, ...There are some trials of $\mathrm{CO}_{2}$ sequestration systems available, but mostly in large single emitter sites. But they are still unproven. Our orientation should be to extract and store - whether in tanks or underground. Underground can be used for large amounts of extraction, but no one is developing small extraction technologies for homes or small offices, where such technology can be diversified throughout cities...

In terms of Technical Focus, one respondent (2) suggested that, ...There is technology available to extract $\mathrm{CO}_{2}$ at the point of emission, but it is not widely used. That is sad. The more such technologies is used and developed, the more likely it will become mainstream...

In terms of Government Leadership, one respondent (5) submitted that, ...I would say clearly 
that letting politicians run the process of developing, finding storage places and then manage it. That would be very dangerous. Better we use scientists and engineers. They should know what they are doing...

In terms of Learning from Other Systems, one respondent (7) pinpointed that, ...Y'know that we had the debacle with nuclear waste deposition, well think about what the problems we will have when we move to $\mathrm{CO}_{2}$ deposition. The nuclear industry is doing no one a favour here, as they will make it very difficult for just as serious issues...

Main Theme - Marketing and Costs:

In terms of Economic Model, one respondent (10) advocated that, ...Economics doesn't seem to work at present for $\mathrm{CO}_{2}$ sequestration. The economic mode that should be adopted is zero-cost - for now. Later, there will need to be a tax model that relates to provision solely for $\mathrm{CO}_{2}$ sequestration - something like a sugar-tax...

In terms of Enabling Technology, one respondent (13) asserted that, ...Like most new technologies, which ones should be used, and for what purpose. Going small, and extracting small amounts with small machines, but having many of them, will in itself have a wide-ranging effect on CCS. The costs are more likely to be borne with larger projects, rather than smaller ones. Infrastructure build should then move to accommodate smaller units and provide regional/city-wide schemes for storage...

In terms of Focus on Profit, one respondent (6) described that, ...the government orientation appears to be - how much money can be made from $\mathrm{CO}_{2}$ sequestration?, rather than on what is good for the environment. This is a negative response. The government has got it wrong. They need to rethink their focus for carbon taxes and place the money in sequestration schemes. No more carbon tax for profit schemes...

In terms of $\mathrm{CO}_{2}$ Marketing, one respondent (12) intimated that, ...Many countries are developing policies now, but no practical engagement. Marketing schemes for $\mathrm{CO}_{2}$ have to be developed. It is folly to work like this, as there is limited funding. It is a disaster that can be mitigated. It will take many years, but it has to start soon....

\section{Discussion}

Consequently, the research discussion for this study targets the final theme outcomes as below:

\subsection{Emissions}

The data suggests that moving the world towards sustainable development will require changes to attitudes and how countries participate in technology development relating to carbon management and capture (Maroto-Valer, 2010) as it is considered a decisive strategy in the mitigation of emissions of $\mathrm{CO}_{2}$ (Leung, Caramanna, \& Maroto-Valer, 2014). Therefore, the need to extract emissions from the atmosphere is directly linked to changing weather patterns associated with rising temperatures above those attributed to the Kyoto protocol (UNFCCC, 1997). 
The presented evidence appears to indicate that the EU does not require CCS developments (CCS Policy \& Regulation, 2009) which is a major barrier to its development. This illustrates clearly the consequences of biased political will of major actors in world climate change through $\mathrm{CO}_{2}$ emissions as CCS technology developments are just beginning or at best slow in its uptake (Toikkaa, Kojo, \& Kainiemi, 2014). However, this must be seen in the context of present CCS mechanisms that overshadow CCS extraction developments that are often associated with a social undertaking, leading to managing sustainable development only from the user-side (Pires, Fidélis, \& Ramos, 2014). Whilst these programmes are useful, they do not offer any underpinning capability to manage - or more importantly - to reduce emissions. Therefore, extraction may become the norm in future considerations of emissions management.

\subsection{Socio-Political Will/Government Strategy}

The data suggests that CCS appears to be a misunderstood technology, and that socio-political support is thus exacerbated by lack of overall education and direction. Political issues appear to influence the major cost of funding research, rather than the essential and necessary scientific basis for the CCS programmes which continue to ignore the overall social cost (IPCC, 2005). However, there are major countries - Western and $3^{\text {rd }}$ world whom resist such measures and would gladly appear to let other countries take the burden of reducing the levels of $\mathrm{CO}_{2}$, whilst they continue to be large primary emitters of $\mathrm{CO}_{2}(\mathrm{Cole}$, 2015; IPCC, 2014). Since it is expected that $3^{\text {rd }}$ world countries will emit $75 \%$ of the global emissions in the next 25 years (EIA, 2007) there is no consensus/agreements on a global solution for this (Ostrom, 2014). This underpins the problems of socio-politics and the significance of the issues raised during the last IPCC world meeting in October in Korea (IPCC, 2018), which is further evidence of the world's political and social indifference when considering $\mathrm{CO}_{2}$ reduction emission polices.

The research data assists the consideration of possible legal frameworks underpinning CCS development, deployment and management that have been assessed (CCS Policy \& Regulation, 2009). However, the level of commitment in providing meaningful measures and opportunities for consistent application and functional scope of CCS technologies remains poor (Karayannis, Charalampides, \& Lakioti, 2014). This also provides barriers to future development/support contributions. Therefore, there is a need to rationalise funding developments that are focused on mitigating climate change, rather than funding programmes associated with popular environmental concerns of less persuasive significance.

\subsection{Technical Development and Underground Strategies}

The data indicates that there is no specific operational scheme to off-set sequestration costs for $\mathrm{CO}_{2}$ or any other greenhouse gas, which could be utilised for the development and installation of $\mathrm{CO}_{2}$ infrastructure, rather than just as a carbon emission price (Talbot, 2014). However, this may be helped through urban schemes where transport and storage are taken under the direct control of governments. Thus, product stewardship notions (Bennet at al., 2018) through civic ecological development (Krasney \& Tidball, 2012) can be used for local $\mathrm{CO}_{2}$ capture, but does not seem appropriate for its transport and storage aspects of CCS 
applications.

Although it was recognised by respondents that more was needed to be done to provide a wider platform for extraction through low-yield, small sustainable capture units (suitable for city buildings). The data clearly indicates that little development has been conducted in such areas (IEA, 2007b) and more research on costs associated with this model of $\mathrm{CO}_{2}$ management needs to be carried out. The EU for example, has promoted a funding programme to support the advances and application of such new technologies (ec.europa.eu, 2018a). The indications are from the data that professional individuals in the community want to develop and use $\mathrm{CO}_{2}$ sequestration - not just recycle their waste - leading to a $\mathrm{CO}_{2}$ sequestration credit (Sanchez et al., 2018) in order to offset $\mathrm{CO}_{2}$ emissions. However, the question of how to engage the ordinary user within a polluted environment using social norms (Huber, Viscussi, \& Bell, 2018) as CCS is not as yet, very well understood (Braun et al., 2018), and differs very little from its 2004 position (Shackley, McLachlan, \& Gough, 2004). The deployment of such sequestration methods is therefore virtually non-existent. This also illustrates the issues surrounding negative emissions (Lenzi, 2018) or a carbon-negative future (Minx et al., 2017). There is also the need to counter Anderson \& Peters' (2016) gloomy notion that such developments would lead to a carbon addiction, as since the $1750 \mathrm{~s}$ society has largely become used to this resource and most find it a necessity. From this, it would appear that the managers of the various research groups recognise the possible impacts of such a strategy would have but cannot provide ways or methods to even translate such ideas on the ground because of a lack of funding (de Coninck, de Best-Waldhober, \& Groenenberg, 2010).

The data advocates that too much emphasis is placed on large surface single-point emitter technology development in terms of underground use of enhanced oil recovery (Green \& Willhite, 2018) - which is presently the only utilised economically viable method for $\mathrm{CO}_{2}$ capture. The wider costs, however, are difficult to determine effectively (Simbeck \& Beecy, 2011). These sequestration processes only become effective if there are large underground geologic storage basins where captured $\mathrm{CO}_{2}$ can be pumped into the available reservoirs (Folger, 2009).

Consequently, there is an obvious imperative for $\mathrm{CO}_{2}$ sequestration (Benson \& Cole, 2008; (IPCC, 2005; MIT, 2018) and an immediate requirement for governments globally to start funding the development, application and sustained process of $\mathrm{CO}_{2}$ sequestration from the atmosphere and store $\mathrm{CO}_{2}$ either in deep geological storage or in suitably framed storage points on the surface (IEA, 2013; Keohane, 2015; IEA, 2017; IChemE Energy Centre, 2018). This is likely to be long term and for some generations it will become a normal activity.

\subsection{Marketing and Costs}

The data and subsequent analysis raised issues revolving around carbon prices and the problems instituting a viable carbon market. To expand on this, in 2015, the US government calculated the social cost of carbon as US\$36 (EPA, 2016), initialising the concept that $\mathrm{CO}_{2}$ markets can be found to fund measures to deal with the expected reductions of $\mathrm{CO}_{2}$ emissions, but not the full costs of emissions (Newbold et al., 2013). However, as depicted earlier in this 
paper, suggestions of user pay's (for emissions) can only go so far because there are speculations that the level of $\mathrm{CO}_{2}$ in the atmosphere could go upto 1300ppm (408ppm at present - NOAA, 2018).

The data analysis further suggests that economic aspects of reducing fossil fuel global energy subsidies (US\$400-600Bn/year - Espa \& Rolland, 2015) would lead to significant reductions of emissions - as much as by $20 \%$ (WHO, 2018). Thus, adding cost to the end user, but would not appear to reduce the overall level of $\mathrm{CO}_{2}$ in the atmosphere. A further issue that was raised from the data was the inability to understand what the level of $\mathrm{CO}_{2}$ prices would be, as in many energy markets, the $\mathrm{CO}_{2}$ pricing appeared to be embedded, hidden and fractured (IEA, 2007a).

This study data has also pointed to the notion that there is a market failure for $\mathrm{CO}_{2}$ sequestration because of market distortion subsidies (Kuntze \& Moerenhout, 2013) and this is possibly one of the issues underpinning why it is an unexplored economic space.

The raised economic pressures of carbon pricing are presently constituted in 2 schemes (World Bank, 2018) - ETS (for example, ec.europa.eu, 2018b) (establishes price of carbon for Greenhouse gases) and Carbon Tax (a defined rate on greenhouse gas emissions). These schemes provide little in the way of an economic incentive to rationalise a system to extract $\mathrm{CO}_{2}$ from the atmosphere. This illustrates that up until now, rather than deal with the emission through carbon capture and storage (CCS) mechanisms and associated technologies, Western countries in particular, prefer an economic model that has a price and therefore an attached profit benefit. This makes individuals pay for greening society requirements, rather than what is required at the industrial level, where governments should pay. Consequently, large single-point emitters will only marginally address the emissions, but not lead to carbon negative outcomes - hence the possible false promise and unclear premise underpinning the present $\mathrm{CO}_{2}$ sequestration motive (Frynas, 2005).

\section{Conclusions}

The data supports the notion that the lack of effective and efficient CCS technologies coupled with its commercial immaturity appears to be related to the inadequate funding directed to climate change research projects (Sanchez et al., 2018; Gibbins \& Chalmers, 2008). Thus, underfunded commercial innovation is a barrier to appropriate CCS developments, which is also attributed to the lack of socio-political outcomes associated with inadequate political will (Lockwood, 2018), an unrealistic commercial undertaking and prevalent profit-based business orientations - negatively requiring making money from carbon emissions through carbon pricing (Klenert et al., 2018). Further, there appears to be a need for a paradigm shift to underpinning strategies to engage grass-roots individuals in order to utilise such emissions reductions technologies.

Politics in general, and political science specifically, realistically remains a challenge in framing the case for climate change (Keohane, 2015), resulting in a hostile, malign politics of populism - polarising and acting against climate change developments (Lockwood, 2018). Further, the present UN Secretary General - Antonio Guterres states unequivocally that if the 
world doesn't make an immediate change by 2020, there is a risk of "runaway climate change" (BBC, 2018), reflecting the "paralysis of leaders". A follow up session of the IPCC (2018) discussed a special report on Global Warming in Korea where there was a failure to determine how to effectively proceed. Further, the UN Secretary General in 2019 stated that there was a "lost opportunity" towards an integrated carbon mitigation agreement for creating a carbon-neutral world by 2050 (UNFCCC, 2019) as the 2018 outcome was echoed. However, this is still considered myopic vision, as the only way forward is to truly mitigate climate change is through $\mathrm{CO}_{2}$ sequestration. This was further exacerbated with another "failure" to engage in climate change at the Madrid Conference of the Parties (COP25, 2019). Nevertheless, it is clear from the evidence that CCS technology development lacks political and financial incentives for its positive implementation (IEA, 2013) resulting in a slow take-up of its possibilities (Scott et al., 2013). Further, a two-stage $\mathrm{CO}_{2}$ sequestration process may need to be thought through, where stage one refers to dealing with current emissions sequestration levels; and stage 2 dealing with the reduction of atmospheric $\mathrm{CO}_{2}$ levels to pre-industrial age levels.

This leads to the contention that CCS is and will become an increased priority to consider and apply (Karayannis, Charalampides, \& Lakioti, 2014). Consequently, $\mathrm{CO}_{2}$ sequestration schemes need to be given more robust standing in the struggle for a carbon-negative future, not just a carbon-zero future especially as present level of "global warming is unparalleled in 2000 years" (BBC, 2019b).

\section{References}

Achinstein, P. (1992). Inference to the Best Explanation: Or, Who Won the Mill-Whewell Debate? Studies in the History and Philosophy of Science Part A, 23(2), 349-364. https://doi.org/10.1016/0039-3681(92)90039-9

Alcalde, J., Smith, P., Haszeldine S., \& Bond, C. (2018). The potential for implementation of Negative Emission Technologies in Scotland. International Journal of Greenhouse Gas Control, 76, 85-91. https://doi.org/10.1016/j.ijggc.2018.06.021

Altheide, D., \& Johnson, J. (1998) Criteria for assessing interpretive validity in qualitative research. In: Denzin, N., Lincoln, Y. (Eds.) Collecting and interpreting qualitative materials. (283-312). Thousand Oaks, CA, USA: Sage Publications.

Anderson, D. (1987). Creativity and the Philosophy of C.S. Peirce. Dordrecht, Netherlands: Springer Nature.

Anderson, K., \& Peters, G. (2016). The trouble with negative emissions. Science, 354(6309), 182-183. https://doi.org/10.1126/science.aah4567

BBC. (2019b). Climate change: Current warming 'unparalleled' in 2,000 years. [Online] Available: https://www.bbc.com/news/science-environment-49086783

BBC. (2019a). 'All at sea over CO2 Storage. [Online] Available:

https://www.bbc.co.uk/sounds/play/p03jrtbv 
BBC. (2018). 'Climate change moving faster than we are,' says UN Secretary General. [Online] Available: https://www.bbc.com/news/science-environment-45471410

Benn, N., Buckingham, S., Domingue, J., \& Mancini, C., (2008). Ontological Foundations for Scholarly Debate Mapping Technology. In: 2nd International Conference on Computational Models of Argument (COMMA '08), Toulouse, France.

Bennett, N., Whitty, T., Finkbeiner, E., Pittman, J., Bassett, H., Gelcich, S., \& Allison, E. (2018). Environmental Stewardship: A Conceptual Review and Analytical Framework. Environmental Management, 61(4), 597-614. https://doi.org/10.1007/s00267-017-0993-2

Benson, S., \& Cole, D. (2008). $\mathrm{CO}_{2}$ Sequestration in Deep Sedimentary Formations. Elements, 4, 325-331. https://doi.org/10.2113/gselements.4.5.325

Bielicki, J. (2009). Spatial clustering and carbon capture and storage deployment. Energy Procedia, 1(1), 1691-1698. https://doi.org/10.1016/j.egypro.2009.01.221

Braun, C., Merk, C., Pönitzsch, G., Rehdanz, K., \& Schmidt, U. (2018). Public perception of climate engineering and carbon capture and storage in Germany: survey evidence. Climate Policy, 18(4), 471-484. https://doi.org/10.1080/14693062.2017.1304888

Cambridge. (2017). New funding for carbon capture and storage. The UK Carbon Capture and Storage Research Centre, Judge Business School, Cambridge University, Cambridge UK. [Online] Available:

https://insight.jbs.cam.ac.uk/2017/new-funding-for-carbon-capture-and-storage/

Carman, J. (1990). Consumer Perceptions of Service Quality: An Assessment of the SERVQUAL Dimensions. Journal of Retailing, 66(1), 33-55.

Cassell, C., \& Symon, G. (2004). Essential Guide to Qualitative Methods in Organizational Research. London, UK: Sage Publications.

CCS Policy and Regulation. (2009). CCS Directive. EU CCS Directive on Geological Storage of Carbon Dioxide (Directive 2009/31/EC). [Online] Available: https://eur-lex.europa.eu/LexUriServ/LexUriServ.do?uri=OJ:L:2009:140:0114:0135:EN:PDF

CCS Research. (2017). Carbon capture: universities and industry work together to tackle emissions. Research, Cambridge University, Cambridge UK. $25^{\text {th }}$ October. [Online] Available: https://www.cam.ac.uk/research/features/carbon-capture-universities-and-industry-work-toget her-to-tackle-emissions

CCS Roadmap. (2012). CCS Roadmap: Supporting deployment of Carbon Capture and Storage in the UK. April. [Online] Available:

https://assets.publishing.service.gov.uk/government/uploads/system/uploads/attachment_data/ file/48317/4899-the-ccs-roadmap.pdf

co2.earth. (2018). Global $\mathrm{CO}_{2}$ Emissions. [Online] Available:

https://www.co2.earth/global-co2-emissions

Cole, D. (2015). Advantages of a polycentric approach to climate change policy. Nature 
Climate Change, 5, 114-118. https://doi.org/10.1038/NCLIMATE2490

COP25. (2019). UN Climate Change Conference - December 2019. Conferences of the Parties, Chile Madrid, $2^{\text {nd }}-13^{\text {th }}$ December. [Online] Available: https://unfccc.int/cop25

de Coninck, H., de Best-Waldhober, M., \& Groenenberg, H. (2010), p67). Regulatory and social analysis for the legitimation and market formation of carbon dioxide $\left(\mathrm{CO}_{2}\right)$ capture and storage technologies, s3.2, 67. In: Maroto-Valer, M. (Ed). Developments and innovation in carbon dioxide (CO2) capture and storage technology, Volume 1: Carbon dioxide (CO2) capture, transport and industrial applications. Cambridge, UK: Woodhead Publishing Limited.

Coombes, C. (2017). Coherence and transparency: some advice for qualitative researchers. Production, 27. https://doi.org/10.1590/0103-6513.006817

COP21. (2015). 2015 Paris Climate Conference. [Online] Available:

http://www.cop21 paris.org/about/cop21/

Daniels, J., Bradley, M., Cramer, D., Winkler, A., Kinebrew, K., \& Crockett, D. (2007). The Successful Resolution of Armed Hostage/Barricade Events in Schools: A Qualitative Analysis. Psychology in the Schools, 44(6), 601-613. https://doi.org/10.1002/pits.20250

Denzin, N., \& Lincoln, Y. (1998). Collecting and Interpreting Qualitative Materials. Thousand Oaks, CA, US: Sage Publications.

Dey, I. (2005). Qualitative data analysis. London, UK: Routledge.

Duranti, A. (2007). Transcripts, like Shadows on a Wall. Mind, Culture, and Activity, 13(4), 301-310. https://doi.org/10.1207/s15327884mca1304_3

ec.europa.eu. (2018b). EU Emissions Trading System. [Online] Available:

https://ec.europa.eu/clima/policies/ets_en

ec.europa.eu. (2018a). Low carbon innovation. [Online] Available:

https://ec.europa.eu/clima/policies/lowcarbon_en

EIA. (2007). International Energy Outlook 2007. Energy Information Administration, Washington, US. [Online] Available: https://www.eia.gov/outlooks/ieo/index.php

EPA. (2016). Technical Support Document: Technical Update of the Social Cost of Carbon for Regulatory Impact Analysis. Under Executive Order 12866, Interagency Working Group on Social Cost of Greenhouse Gases, United States Government. August. [Online] Available: https://www.epa.gov/sites/production/files/2016-12/documents/sc_co2_tsd_august_2016.pdf

Espa. I., \& Rolland, S. (2015). Subsidies, Clean Energy, and Climate Change. E15Initiative. Geneva: International Centre for Trade and Sustainable Development (ICTSD) and World Economic Forum. [Online] Available: www.e15initiative.org/

Folger, P. (2009). Carbon Capture and Sequestration (CCS). Congressional Research Service Reports, Paper 44, 7-5700, $19^{\text {th }}$ June. [Online] Available: 
http://digitalcommons.unl.edu/crsdocs/44

Frynas, J. (2005). The false developmental promise of Corporate Social Responsibility: evidence from multinational oil companies. International Affairs, 81(3), 581-598.

https://doi.org/10.1111/j.1468-2346.2005.00470.x

Gibbins, J., \& Chalmers, H. (2010). Fossil Power Generation with Carbon Capture and Storage (CCS): Policy Development for Technology Deployment. In: Hester, R., \& Harrison, R. (Eds), Carbon Capture Sequestration and Storage. Cambridge, UK: RSC Publishing, The Royal Society of Chemistry.

Gibbins, J., \& Chalmers, H. (2008). Carbon capture and storage. Energy Policy, 36(12), 4317-4322. https://doi.org/10.1016/j.enpol.2008.09.058

Glaser, B. (1992). Basics of Grounded Theory Analysis., Mill Valley, CA, USA: Sociology Press.

globalccsinstitute.com. (2018). Large Scale CCS Projects. [Online] Available:

https://www.globalccsinstitute.com/projects/large-scale-ccs-projects

Gonzalez, C. (2008). Conceptions of, and approaches to, teaching online: a study of lecturers teaching postgraduate distance courses. Higher Education, 57(3), 299-314.

https://doi.org/10.1007/s10734-008-9145-1

Gray, J., \& Wilcox, B. (1995). Good Schools, Bad Schools. Buckingham, UK: Open University Press.

Green, D., \& Willhite, P. (2018). Enhanced Oil Recovery. Richardson, Texas, USA: Society of Petroleum Engineers.

Hammond, G., Akwe, S., \& Williams, S. (2011). Techno-economic appraisal of fossil-fuelled power generation systems with carbon dioxide capture and storage. Energy, 36(2), 975-984 https://doi.org/10.1016/j.energy.2010.12.012

Hansson, A., \& Bryngelsson, M. (2009). Expert opinions on carbon dioxide capture and storage - A framing of uncertainties and possibilities. Energy Policy, 37(6), 2273-2282. https://doi.org/10.1016/j.enpol.2009.02.018

Harris, L., \& Brown, G. (2010). Mixing interview and questionnaire methods: Practical problems in aligning data. Practical Assessment, Research and Evaluation, 15(1), 1-19.

Harwood, T., \& Garry, T. (2003). An Overview of Content Analysis. The Marketing Review, 3(4), 479-498. https://doi.org/10.1362/146934703771910080

Hill, C., Thompson, B., \& Williams, E. (1997). A guide to conducting consensual qualitative research. The Counseling Psychologist, 25(4), 517-572.

https://doi.org/10.1177/0011000097254001

Horn, F., \& Steinberg, M. (1982). Control of carbon dioxide emissions from a power plant (and use in enhanced oil recovery). Fuel, 61(5), 415-422. 
https://doi.org/10.1016/0016-2361(82)90064-3

Huber, J., Viscussi, K., \& Bell, J. (2018). Dynamic relationships between social norms and pro-environmental behavior: evidence from household recycling. Behavioural Public Policy, 1-25. Cambridge University Press. https://doi.org/10.1017/bpp.2017.13

IChemE Energy Centre. (2018). A Chemical Engineering Perspective on the Challenges and Opportunities of Delivering Carbon Capture and Storage at Commercial Scale. April. [Online] Available:

http://www.icheme.org/ /media/Documents/icheme/Media\%20centre/Energy-centre/2018\%2 0CCS\%20Report\%20FINAL.pdf

IEA. (2017). Five keys to unlock CCS investment. International Energy Agency (IEA), Paris, France. [Online] Available: https://www.iea.org/media/topics/ccs/5KeysUnlockCCS.PDF

IEA. (2013). Technology Roadmap Carbon Capture and Storage. International Energy Agency (IEA), Paris, France. [Online] Available:

https://www.iea.org/publications/freepublications/publication/TechnologyRoadmapCarbonCa ptureandStorage.pdf

IEA. (2009). Technology Roadmap: Carbon Capture and Storage. International Energy Agency (IEA), Paris, France. [Online] Available:

https://webstore.iea.org/technology-roadmap-carbon-capture-and-storage-2009

IEA. (2007b). Distributed Collection of $\mathrm{CO}_{2}$. IEA Greenhouse Gas R\&D Programme (IEA GHG), Report Number - 2007/12, Cheltenham, UK, September. [Online] Available: https://ieaghg.org/docs/General_Docs/Reports/2007-12_Distributed\%20CO2\%20collection.p df

IEA. (2007a). $\mathrm{CO}_{2}$ Allowance \& Electricity Price Interaction. [Online] Available: https://www.iea.org/publications/freepublications/publication/jr_price_interaction.pdf

IPCC. (2018). Summary for Policymakers of IPCC Special Report on Global Warming of $1.5^{\circ} \mathrm{C}$ approved by governments. October. [Online] Available:

https://www.ipcc.ch/2018/10/08/summary-for-policymakers-of-ipcc-special-report-on-globalwarming-of-1-5c-approved-by-governments/

IPCC. (2014). Climate Change 2014: Mitigation of Climate Change Summary for Policymakers. Contribution of Working Group III to the Fifth Assessment Report of the Intergovernmental Panel on Climate Change, IPCC. Cambridge University Press: Cambridge, United Kingdom and New York. [Online] Available: http://www.ipcc.ch/report/ar5/

IPCC. (2007). IPCC fourth assessment report: climate change 2007. [Online] Available: https://ipcc.ch/report/ar4/

IPCC. (2005). Underground geological storage. In: Metz, B., Davidson, O., de Coninck, H., Loos, M., \& Meyer, L. (eds). IPCC Special Report on Carbon Dioxide Capture and Storage. Working Group III of the Intergovernmental Panel on Climate Change. Cambridge, UK: Cambridge University Press. 
James, P. (2015). Social Media Marketing Developments in Private Hospitals in Bangkok. The Internet Journal of Healthcare Administration, 11(1).

https://doi.org/10.5580/IJHCA.35596

James, P., James, T. (2011). Qualitative Research Methods for Health Services. London, UK: Megellan UK Press.

Johnson, B. (1997). Examining the validity structure of qualitative research. Education, $118(3), 282-292$.

Kaiser, K. (2009). Protecting Respondent Confidentiality in Qualitative Research. Qualitative Health Research, 19(1), 1632-1641. https://doi.org/10.1177/1049732309350879

Karayannis, V., Charalampides, G., \& Lakioti, E. (2014). Socio-economic aspects of CCS technologies. Procedia Economics and Finance. International Conference on Applied Economics (ICOAE) 2014, 14, 295-302. https://doi.org/10.1016/S2212-5671(14)00716-3

Kennedy, C. (2009). Carbon Dioxide: Earth's Hottest Topic is Just Warming Up. $21^{\text {st }}$ October. [Online] Available:

https://www.climate.gov/news-features/understanding-climate/carbon-dioxide-earths-hottest-t opic-just-warming

Keohane, R. (2015). The Global Politics of Climate Change: Challenge for Political Science. Political Science, The 2014 James Madison Lecture: The Global Politics of Climate Change, January. https://doi.org/10.1017/S1049096514001541

Kim, Y. (2011). The Pilot Study in Qualitative Inquiry: Identifying Issues and Learning Lessons for Culturally Competent Research. Qualitative Social Work, 10(2), 190-206. https://doi.org/10.1177/1473325010362001

Klenert, D., Mattauch, L., Combet, E., Edenhofer, O., Hepburn, C., Rafaty, R., \& Stern, N. (2018). Making carbon pricing work for citizens. Nature Climate Change, 8(8), 669-677. https://doi.org/10.1038/s41558-018-0201-2

Krasney, M., \& Tidball, K. (2012). Civic ecology: a pathway for Earth Stewardship in cities. Frontiers in Ecology and the Environment, 10(5), 267-273. https://doi.org/10.1890/110230

Kuntze, J., \& Moerenhout, T. (2013). Local Content Requirements and the Renewable Energy Industry - A Good Match? ICTSD Global Platform on Climate Change, Trade and Sustainable Energy, Geneva, Switzerland. [Online] Available:

http://www.ictsd.org/sites/default/files/research/2013/06/local-content-requirementsand-the-r enewable-energy-industry-a-good-match.pdf

Kvale, S. (1996). Interviews: An Introduction to Qualitative Research Interviewing. Thousand Oaks, CA, US: Sage Publications.

Lambsdorff, G. (1998). An Empirical Investigation of Bribery in International Trade. European Journal for Development Research, 10(1), 40-59.

https://doi.org/10.1080/09578819808426701 


\section{Macrothink}

Environmental Management and Sustainable Development

ISSN 2164-7682

2020, Vol. 9, No. 1

Lenzi, D. (2018). The ethics of negative emissions. Global Sustainability, 1(e7), 1-8. https://doi.org/10.1017/sus.2018.5

Leung, D., Caramanna, G., \& Maroto-Valer, M. (2014). An overview of current status of carbon dioxide capture and storage technologies. Renewable and Sustainable Energy Reviews, 39, 426-443. https://doi.org/10.1016/j.rser.2014.07.093

Lincoln, Y., \& Guba, E. (1985). Naturalistic Inquiry. Beverly Hills, CA, USA: Sage Publications.

Lockwood, M. (2018). Right-wing populism and the climate change agenda: exploring the linkages, Environmental Politics. Environmental Politics, 27(4), 712-732.

https://doi.org/10.1080/09644016.2018.1458411

Maroto-Valer, M. (2010). Developments and Innovation in Carbon Dioxide (CO2) Capture and Storage Technology. Cambridge, UK: Woodhead Publishing.

Maxwell, J. (2013). Qualitative Research Design: An Interactive Approach. London, UK: Sage Publications.

Michael, K., Golab, A., Shulakova, V., Ennis-King, J., Allinson, G., Sharma, S., \& Aitkin, T. (2009). Geological storage of $\mathrm{CO} 2$ in saline aquifers - A review of the experience from existing storage operations. International Journal of Greenhouse Gas Control, 4, 659-667. https://doi.org/10.1016/j.ijggc.2009.12.011

Middleton, R., Bielicki, J., Keating, G., \& Pawar, R. (2011). Jumpstarting CCS using refinery $\mathrm{CO}_{2}$ for enhanced oil recovery. Energy Procedia, 4, 2185-2191.

https://doi.org/10.1016/j.egypro.2011.02.105

Minx, C., Lamb, W., Callaghan, M., Bornmann, L., \& Fuss, S. (2017). Fast growing research on negative emissions. Environmental Research Letters, 12(3), 1-11.

https://doi.org/10.1088/1748-9326/aa5ee5

MIT. (2018). Maybe we can afford to suck $\mathrm{CO}_{2}$ out of the sky after all. $7^{\text {th }}$ June. [Online] Available:

https://www.technologyreview.com/s/611369/maybe-we-can-afford-to-suck-cosub2sub-out-o f-the-sky-after-all/

Newbold, S., Griffiths, C., Moore, C., Wolerton, A., \& Kopits, E. (2013). A Rapid Assessment Model for Understanding the Social Cost of Carbon. Climate Change Economics, 4, 1 https://doi.org/10.1142/S2010007813500012

NOAA. (2018). Global Climate Change. July. [Online] Available:

https://climate.nasa.gov/vital-signs/carbon-dioxide/

Noble, H., \& Mitchell, G. (2016). What is grounded theory? Evidence-Based Nursing, 19, 34-35. http://dx.doi.org/10.1136/eb-2016-102306

OECD. (2012). The Technology Roadmap: Carbon Capture and Storage in Industrial Applications. OECD, International Energy Agency \& United Nations, Industrial 
Development Organization, 2011

onlyzerocarbon.org. (2018). Atmospheric CO2 Concentrations. [Online] Available: http://www.onlyzerocarbon.org/co2_levels.html

Ostrom, E. (2014). A Polycentric Approach for Coping with Climate Change. Annals of Economics and Finance, 15(1), 97-134.

Pires, S., Fidélis, T., \& Ramos, T., (2014). Measuring and comparing local sustainable development through common indicators: Constraints and achievements in practice. Cities, 39, 1-9. https://doi.org/10.1016/j.cities.2014.02.003

Punch, K. (2014). Introduction to Social Research: Quantitative and Qualitative Approaches. London, UK: Sage Publications.

Qu, S., \& Dumay, J. (2011). The qualitative research interview. Qualitative Research in Accounting \& Management, 8(3), 238-264. https://doi.org/10.1108/11766091111162070

Quadrelli, E., Centi, G., Duplan, J., \& Perathoner, S. (2011). CO2 recycling: emerging large-scale technologies with industrial potential. ChemSusChem, 4, 1194-1205.

https://doi.org/10.1002/cssc.201100473

Rackley, S. (2017). Carbon Capture and Storage. Oxford, UK: Butterworth-Heinemann.

Ritchie, J., Lewis, J. (2003). Qualitative Research Practice: A Guide for Social Science Students and Researchers. London, UK: Sage Publications.

Rubin, H., \& Rubin, I. (2005). Qualitative Interviewing: The Art of Hearing Data. Thousand Oaks, CA, USA: Sage Publications.

Sanchez, D., Johnson, N., McCoy, S., Turner, P., \& Mach, K. (2018). Near-term deployment of carbon capture and sequestration from biorefineries in the United States. PNAS, 1-6, $18^{\text {th }}$ March. https://doi.org/10.1073/pnas.1719695115

Scott, V., Gilfillan, S., Markusson, N., Chalmers, H., \& Haszeldine, R. (2013). Last chance for carbon capture and storage, Nature Climate Change, 3, 105-111.

https://doi.org/10.1038/nclimate1695

Seale, C., \& Silverman, D. (1997). Ensuring rigour in qualitative research. European Journal of Public Health, 7(4), 379-384. https://doi.org/10.1093/eurpub/7.4.379

Seifritz, W. (1990). $\mathrm{CO}_{2}$ disposal by means of silicates. Nature, 345(6275), 486.

https://doi.org/10.1038/345486b0

Shackley, S., McLachlan, C., Gough, C. (2004). The public perception of carbon dioxide capture and storage in the UK: results from focus groups and a survey. Climate Policy, 4(4), 377-398. https://doi.org/10.1080/14693062.2004.9685532

Shearman, S. (2018). Deep sea trenches eyed for carbon dioxide storage. Financial Times, March 29, 2018. [Online] Available:

https://www.ft.com/content/1a008448-de6f-11e7-a0d4-0944c5f49e46 
Simbeck, D., \& Beecy, D. (2011). The CCS paradox: The much higher $\mathrm{CO}_{2}$ avoidance costs of existing versus new fossil fuel power plants. Energy Procedia, 4, 1917-1924. https://doi.org/10.1016/j.egypro.2011.02.071

Spanos, A. (1990). Towards a Unifying Methodological Framework. In: William, C., \& Granger, J. Readings in Econometric Methodology, Oxford, UK: Clarendon Press.

Stenbacka, C. (2001). Qualitative research requires quality concepts of its own. Management Decision, 39(7), 551-556. https://doi.org/10.1108/EUM0000000005801

Strauss, A., \& Corbin, J. (1990). Basics of Qualitative Research: Grounded Theory, Procedures and Techniques. Newbury Park, Chicago, USA: Sage Publications.

Sutton, J., \& Austin, Z. (2015). Qualitative research: data collection, analysis management. The Canadian Journal of Hospital Pharmacy, 68(3), 226-231.

https://doi.org/10.4212/cjhp.v68i3.1456

Talbot, D. (2014). Carbon Sequestration: Too Little, Too Late? MIT Technology Review, $13^{\text {th }}$ Oct. [Online] Available:

https://www.technologyreview.com/s/531531/carbon-sequestration-too-little-too-late/

The Clean Growth Strategy. (2017). The Clean Growth Strategy, Leading the way to a low carbon future. October. [Online] Available:

https://www.gov.uk/government/publications/clean-growth-strategy

Toikkaa, A., Kojob, M., \& Kainiemi, L. (2014). What is the Socio-Political Scaffolding CCS Needs to Thrive? Case Study from Finland. Energy Procedia, 63, 7119-7124. https://doi.org/10.1016/j.egypro.2014.11.747

UNFCCC. (2019). Statement by the UN Secretary-General Antonio Guterres on the Outcome of COP25, UN Climate Statement, $15^{\text {th }}$ Dec 2019. [Online] Available:

https://unfccc.int/news/statement-by-the-un-secretary-general-antonio-guterres-on-the-outco me-of-cop25

UNFCCC. (1997). The Kyoto Protocol, UNFCCC. [Online] Available: https://unfccc.int/process/the-kyoto-protocol/status-of-ratification

Vatalis, K., Manoliadis, O., Charalampides, G., Platias, S., \& Savvidis, S. (2013). Sustainability components affecting decisions for green building projects. Procedia Economics and Finance, 5, 747-756. https://doi.org/10.1016/S2212-5671(13)00087-7

Ward, P., Rokkas, P., Cenko, C., Pulvirenti, M., Dean, N., Carney, S., Brown, P., Calnan, M., \& Meyer, S. (2015). A qualitative study of patient (dis)trust in public and private hospitals: the importance of choice and pragmatic acceptance for trust considerations in South Australia. BMC Health Services Research, 15(1), 297-308. https://doi.org/10.1186/s12913-015-0967-0

WHO. (2018). A global health guardian: climate change, air pollution, and antimicrobial resistance. [Online] Available:

http://www.who.int/publications/10-year-review/health-guardian/en/ 


\section{Macrothink \\ Environmental Management and Sustainable Development \\ ISSN 2164-7682 \\ 2020, Vol. 9, No. 1}

World Bank. (2018). Pricing Carbon. [Online] Available:

http://www.worldbank.org/en/programs/pricing-carbon

World Meteorological Organization. (2018). WMO Statement on the state of the global climate in 2017. [Online] Available:

https://public.wmo.int/en/our-mandate/climate/wmo-statement-state-of-global-climate

\section{Copyright Disclaimer}

Copyright for this article is retained by the author(s), with first publication rights granted to the journal.

This is an open-access article distributed under the terms and conditions of the Creative Commons Attribution license (http://creativecommons.org/licenses/by/3.0/). 